\section{THE RIGHTS OF}

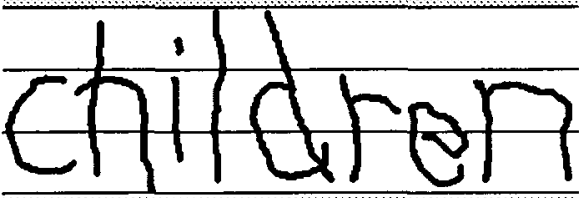

In a Special issue of

HUMAN RIGHTS QUARTERLY

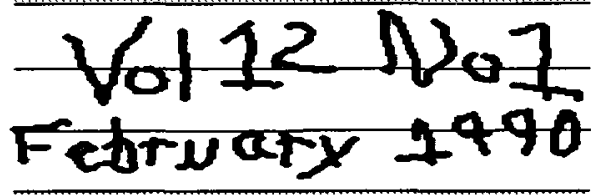

A Comparative and International Journal of the Soclal Sclences, Humanitles, and Law

Editedo, BertB, ockwood, It publishod by tho lohns 10 pkins University Press sponsorodby tho Urban Morgan Institute 1 or Human Rights. Universty of Gncinati Schoot of aw
Contents

- The UN Convention on the Rights of the Child and How to Make it Work-

Thomas Hammarberg

- The Unborn Child and Abortion Under the Draft Convention on the Rights of the ChildPhilip Alston

- Advocacy of Children's Rights-The Convention as more than a Legal DocumentPeter Miljeteig-Olssen

- The Draft Convention on the Rights of the Child: New RightsJaime Sergio Cerda

- The UN Convention on the Rights of the Child: An Opportunity for AdvocatesMichael Jupp - And More! coples of Human Rights Quarterly Vol 12 No 1 on "The Rights of Children"I $\square$ Individual \$7.50 $\square$ Institution $\$ 17.00$

Please enter my one-year subscription to Human Rights Quarterly starting with the special issuel $\square$ Individual $\$ 25.00 \square$ institution $\$ 46.00$
$\square \mathrm{C}$
Check/money order enclosed
MasterCard
VISA Acct. \# Exp. Date

Signature

Name

Address

City/State/Zip

Send orders with payment to: The Johns Hopkins University Press, Journals Division, 701 W. 40th Street, Sulte 275, Baltimore, MD 21211. Or call our toll-free number: 1-800-537-JHUP to charge orders to your MasterCard or VISA. Prepayment is required before shipment. Subscribers in Mexico and Canada add $\$ 4.20$ postage; outside North America add $\$ 7.50$ air freight. Payment must be drawn on a U.S. bank or made by international money order, payable to Johns Hopkins University Press. Maryland residents add $5 \%$ sales tax. 
Comparative Studies in Society and History is a forum for presentation and discussion of new research into problems of change and stability that recur in human societies through time or in the contemporary world. It sets up a working alliance between specialists in all branches of the social sciences and humanities. Debate and review articles bring the general reader in touch with current findings and issues.

\section{NOTES FOR CONTRIBUTORS}

Contributions may be descriptive, analytical, or theoretical. Any article not in itself comparative may be accepted if it lends itself to comment that will place it in comparative perspective. Correspondence with the editors prior to the submission of articles will help to enable them to obtain such comment or a companion study. Emphasis in comparative studies may be either on similarities or, if these are significant enough and call for some recasting of generalizations, on differences. All contributions and editorial correspondence should be sent to the Editors, Comparative Studies in Society and History, 102 Rackham Building, University of Michigan, Ann Arbor, Michigan 48109-1070.

Two copies of each contribution, preferably accompanied by a stamped, addressed envelope, should be submitted. Both text and footnotes should be clearly typed with double spacing and wide margins; footnotes should appear on separate pages at the end of the article. Illustrations may be included by arrangement with the editors. 
Volume $32 \quad$ Number $2 \quad$ April 1990

\section{COMPARATIVE STUDIES IN SOCIETY AND HISTORY}

Editorial Foreword $199-200$

The Politics of Terror

Timothy P. Wickham-Crowley Terror and Guerrilla Warfare in Latin America, 1956-1970

William A. Douglass and Joseba Zulaika On the Interpretation of Terrorist Violence: ETA and the Basque Political Process

NATHAN Brown Brigands and State Building: The Invention of Banditry in Modern Egypt

\section{Power and Popular Culture}

Vicente L. Rafael Patronage and Pornography: Ideology and Spectatorship in the Early Marcos Years

Cheryl English Martin Popular Speech and Social Order in Northern Mexico, 1650-1830

The Culture of Social Organizations

Peter McDonough Metamorphoses of the Jesuits: Sexual Identity, Gender Roles, and Hierarchy in Catholicism

JoHN R. EIDSON German Club Life as a Local Cultural System

\section{CSSH Discussion}

Gyan Prakash Writing Post-Orientalist Histories of the Third World: Perspectives from Indian Historiography CSSH Notes

\section{Cambridge University Press}

The Edinburgh Building, Shaftesbury Road, Cambridge CB2 2RU

40 West 20th Street, New York, NY 10011

10 Stamford Road, Oakleigh, Melbourne 3166, Australia

(C) 1990 Society for the Comparative Study of Society and History

Printed in the United States of America 